\title{
There were giants upon the earth in those days
}

RHINOCEROS GIANTS: THE PALEOBIOLOGYOF INDRICOTHERES. By Donald R. Prothero. Life of the Past Collection, Indiana University Press; 160 pp. (66 b\&w illustrations). Hardback (7x10"): USD 42.00 plus shipping. ISBN: 978-0-25300819-0. E-book: USD 34.99. ISBN: 978-0-253-00826-8

\author{
PIERRE-OLIVIER ANTOINE \\ Institut des Sciences de l'Evolution, Université Montpellier 2, CNRS, IRD Place Eugène Bataillon, F-34095 Montpellier, France \\ E-mail: pierre-olivier.antoine@univ-montp2.fr
}

Keywords: Rhinocerotoidea; Indricotheriinae; Eurasia; Paleogene; history of science

(C) Copyright Pierre-Olivier Antoine July 2014

Imagine a twenty tonne rhinoceros without a horn, but with a sloppy back similar to that of an okapi and (almost) as long-necked as a sauropod dinosaur! You got it? Call it an indricothere and fully immerse yourself in Donald Prothero's latest book, to learn about their life, history, and systematics.

The cover has a very provocative illustration of indricotheres, with elephant-like heads (trunk, immense ears), chimerical giraffe-rhino body and neck, and slender three-toed legs. The nostrils are drawn laterally open, which is particularly puzzling (i.e., what is the tip of the trunk made of, what would have been its use?)... I must admit I am not really convinced by this idea of elephant-like indricotheres (see below for more discussion)! However, the rendering is splendid, due to Carl Buell's talented hand (and graphic tablet).

On the back cover, the appealing sentence "The life and times of the largest land animal that ever lived" is unfortunate, as the weight-and-size leadership of indricotheres is seriously challenged by several extinct proboscideans at mammalian scale (see Fortelius \& Kappelman, 1993), and also because those rhino giants were dwarves with respect to other land animals - though much earlier - such as Mesozoic long-necked sauropod dinosaurs.

The Frontispiece mentions this book as "the culmination of over thirty-five years' worth of research on fossil rhinoceroses", launched by a visit to the Frick and American Museum of Natural History (AMNH) collections in 1976. In the meantime, Donald Prothero also has a proven lively sense of humor (e.g., p. 8, learn how he is only "three degrees of separation from Darwin") and provocation, as well as a wide expertise on the evolution and distribution of extinct hoofed mammals, be they odd- or even-toed. Indeed, he has been a very prolific book editor and author for the last 25 years ("The Evolution of Perissodactyls": Prothero \& Schoch, 1989; "The Terrestrial Eocene-Oligocene Transition in North America": Prothero \& Emry, 2005; "The Evolution of North American Rhinoceroses": Prothero, 2005; "After the Dinosaurs: the Age of Mammals": Prothero, 2006; "The Evolution of Artiodactyls": Prothero \& Foss, 2007).

After a short preface, this reader-friendly 160 page-long book offers seven chapters with appealing titles (Quicksand!; 30 Million Years Ago in Asia; "New Conquest of Central Asia"; Rhinoceroses without Horns; Building a Giant; What's in a Name?; Life among Giants), as well as a comprehensive bibliographic section and an exhaustive index for taxa, localities, scientists, and whatever your topic of interest may be.
The illustration alternates historical pictures and photographs, beginning with an astonishing caravan of the American Museum Mongolian expeditions in 1922-1930 (what a budget, especially with respect to that of recent expeditions!). Many of the 59 black-and-white figures are provided courtesy of museum libraries or giant rhino-friendly colleagues. Unfortunately, the halftone printing is of average rendering for several figures.

The first chapter (“Quicksand!", pp. 1-16) interweaves the stories and histories of a handful of major $20^{\text {th }}$ century fossil hunters and/or paleontologists, such as Roy Chapman Andrews, Henry Fairfield Osborn, Walter Granger, William King Gregory, Guy E. Pilgrim, or Clive Forster-Cooper. The first story relates the discovery of an indricothere individual that died standing upright in quicksand, and from which only hands and feet were preserved, as found by members of the American Museum Mongolian expedition 25 to 30 million years later. Above all, this chapter provides an opportunity to profile colorful characters such as Roy Chapman Andrews ("the real Indiana Jones?", who started as a janitor at the AMNH before he got a Master's degree in mammalogy at Columbia University) or Walter Granger ("a self-taught paleontologist"). However, there is no question that the most enjoyable portrait focuses on Henry Fairfield Osborn (p. 8 onward), depicted as a wealthy Ivy League schoolmate, recently graduated from Princeton, and then becoming the "superb administrator and genius at fund-raising" each and every vertebrate paleontologist knows. More interesting is the follow-up, with H.F. Osborn portrayed as a "follower of eugenics and racist anthropology and advocate policies toward non-white races that are offensive today" (pp. 8-9). Prothero insists on Osborn's idiosyncratic and outdated paleontological notions, having led him to endorse "racial senescence", "aristogenesis", or the Piltdown skull (p. 9). The chapter also highlights his notorious use and abuse of ghost writers (let us call them "subordinates").

Regarding giant rhinos themselves, the account of Gobi Desert expeditions is splendid, with breathtaking quotations, especially on the first discovery of "isolated bones as large as a man's body" (fig. 1.5, p. 12), and the finding of the famous AMNH 18650 skull of Baluchitherium grangeri, still exhibited 6 meters above the ground at the AMNH.

The second chapter, "Giant Hunters" (pp. 17-34), depicts most discoveries of giant rhinos throughout the last century in Baluchistan, Mongolia, Kazakhstan, or China, but also more recently in Turkey. Donald Prothero lauds Guy E. Pilgrim, a "true pioneer" traveling to Persia, Baluchistan, Arabia and 
Burma, or Bhutan, and unraveling the geology and paleontology of such remote areas. Interestingly, fig. 2.1 (p. 18) illustrates the first map of indricothere-yielding regions of Asia, by Osborn (1923), with Baluchistan as a separate entity (Pakistan was not yet a country). Pilgrim (1910) was "the first to discover and name indricothere specimens", referred to as "Aceratherium bugtiense", a species still valid today, even if the genus concerned has long proven to gather true rhinos (i.e. rhinocerotids) instead of hyracodontids. Then Forster-Cooper (1911) assigned this species to a new genus, Paraceratherium, which has a bunch of junior synonyms (including "Thaumastotherium Forster Cooper, 1913", "Indricotherium Borissiak, 1915", or "Baluchitherium Osborn, 1923" for the most famous of them). Later on, as a Director of the British Museum of Natural History (BMNH), Forster-Cooper organized the move of the BMNH collections to Tring, $50 \mathrm{~km}$ away from London, before the city got repeatedly and severely bombed by the Luftwaffe during World War II [Unfortunately, a similar catastrophe had not been anticipated sixty five years later, when most giant rhino remains unearthed by the French-Balochi expeditions in the Bugti Hills (1995-2004), led by Jean-Loup Welcomme, were bombed away in Dera Bugti in April 2006]. Donald Prothero then shifts to the Turgai area in Kazakhstan, where the origin of "Indricotherium", a genus named by Borissiak (1915) after the fabulous "Indrik beast" of the Russian folklore, is to be found. Along a timeline, he depicts a brief history of Chinese paleontology and early pioneers, evoking the first giant rhino discoveries from China (Inner Mongolia) by Teilhard de Chardin (1926) or the recognition of the earliest indricothere, the middle Eocene four-toed Juxia, by Chow \& Chiu (1964).

"Land of the Giants" (pp. 35-51) encompasses contemporary findings of indricotheres (1970s onward), mostly in regions having already yielded giant rhino remains in the past, such as Baluchistan ("Welcomme years"; 1995-2004), Mongolia, China, or Kazakhstan. However, a short section is dedicated to isolated - and somewhat puzzling - specimens found in Eastern Europe (Romania, Bulgaria) and the Caucasus (Benara, Georgia). Finally, the ongoing history, with recent finds and continuing efforts south to the Black Sea, in upper Oligocene deposits of Turkey, both in North Central Anatolia (Antoine et al., 2008) and close to the Armenian border (Sen et al., 2011) [Coincidentally, at the time of writing, I am flying over Balkans, to join a Turkish team for excavating a newly found skeleton of Paraceratherium in the Çankırı-Çorum Basin, North Central Anatolia].

The book then extends its scope ("Rhino Roots", pp. 52-66), with a summary of early rhino evolution. These small and hornless forest dwellers experienced a huge specific diversity in mid-Cenozoic times, especially in northern landmasses. Prothero puts the indricotheres into their systematic context: indricotheres were giant representatives of Hyracodontidae, the family sister group to that of Recent rhinos (Rhinocerotidae). That extinct family encompassed both giant rhinos and much smaller forms (hyracodontines, goat-sized) during the Eocene-Oligocene interval.

In "What's in a name?" (pp. 67-86), the author exposes the basics of systematics, nomenclature, and taxonomy as being "the rules of the road" (principles of priority and coordination, definition of type specimens). He exemplifies these rules using indricothere systematics, thus clarifying their generic assignments and synonymy (with the continuing struggle between "splitters" and "lumpers" as a background). Accordingly, Paraceratherium Forster-Cooper, 1911 has priority over other generic names, if all Oligocene indrico- theres are to be gathered within a single genus (which might be doubtful at least for Dzungariotherium orgosensis, which has a pretty distinctive mandible). To support his assumption, Prothero extrapolates the hypothesized "home range" $(1,000$ $\mathrm{km} 2$ ) and undisputed dispersal ability of indricotheres, based on those of recent large-bodied land mammals. Be that as it may, a comprehensive phylogenetic analysis is still badly needed to make a decisive statement on that long running debate.

The next chapter ("Building a Giant", pp. 87-106) focuses on the reconstruction of indricotheres, starting with that of the unrivalled American Museum skull (fig. 6.1, p. 88; Granger \& Gregory, 1936), then providing details on the okapi-like early indricothere Juxia, as provided by Qiu \& Wang, 2007). Therein (p. 90) lies the explanation for the "elephant ear" hypothesis, with ears as giant air-conditioners for those warm-blooded beasts, living in supposedly warm Oligocene times! Much more convincing is the interpretation of indricotheres as unguligrade runners, based on their autopodial morphology and regardless of their huge size. In "Putting flesh on the skeleton", Prothero maps out life restorations of giant rhinos, beginning with Osborn's (1923) Indian rhino-like reconstruction, long proven to be incorrect in most proportions. Prothero and I agree that the most remarkable skeleton reconstruction of all times was provided by Gromova (1959), from a partial individual unearthed in the Aral Sea region, Kazakhstan. The follow-up ("Constraints on Giants", pp. 100-103) focuses on speculative constraints such as thermoregulation (life by water puddles; skin color similar to that of living elephants), digestion (hindgut fermenters, as all perissodactyls; huge amount of daily food), locomotion, home range, predation, and life habits (e.g., unrivalled longevity expected). Naturally, the chapter ends up with body weight estimates ("Weight problems", pp. 103-106), ranging from 5 up to 34 tonnes - depending on proxies and/or authors -, with reasonable estimates around 15-17 tonnes.

The last section ("Paradise Lost", pp. 107-121) discloses climatic hazards in deep time, from the greenhouse of the dinosaurs to the Big Chill (Eocene-Oligocene cooling episode, coeval to the "Grande Coupure", c. 34 Mya), and highlights their bearing on life and distribution of land mammals in general. In "Where have all the giants gone?", the causes of giant rhino extinction are evoked, ranging from life-history traits (huge body size and presumed slow reproductive rate) to environmental changes, or interspecific competition with other megaherbivores (e.g., rhinocerotids and new incomers, such as proboscideans). As usual, those parameters may have interacted, which eventually led to the disappearance of those giants by the end of the Oligocene epoch: "all we have is their incredibly huge skeletons to inspire awe and amazement and to give us a window into a world long gone" (p. 121).

Donald R. Prothero is second to none for telling stories, as well as for revealing a well-documented and pretty convincing history of other "giants of the past", such as Osborn, Pilgrim, or Forster-Cooper, still brightened by a collection of off-therecord anecdotes. To my knowledge, no other paleontological book manages to paint such a story against such a prominent economic and political background (Great Depression; World Wars I and II; decolonization; Cold War; Soviet Union rise and demise; Cultural Revolution). As usual, Don teaches us with an unrivalled sense of humor and no fear of political incorrectness. I dig that! 


\section{BIBLIOGRAPHY}

Antoine, P.-O., Karadenizli, L., Saraç, G., Sen, S., 2008. A giant rhinocerotoid (Mammalia, Perissodactyla) from the Late Oligocene of north-central Anatolia (Turkey). Zoological Journal of the Linnean Society 152, 581-592.

Borissiak, A. A., 1915. Ob indrikoterii (Indricotherium n.g.). Geologiskie Vestnik 1, 131-134.

Chow, M., Chiu, C., 1964. An Eocene giant rhinoceros. Vertebrata PalAsiatica 8, 264-267.

Forster-Cooper, C., 1911. Paraceratherium bugtiense, a new genus of Rhinocerotidae from the Bugti Hills of Baluchistan. Preliminary notice. Annual Magazine of natural History 8, 711-716.

Fortelius, M., Kappelman, J., 1993. The largest land mammal ever imagined. Zoological Journal of the Linnean Society 108, 85-101.

Granger, W., Gregory, W. K., 1936. Further notes on the gigantic extinct rhinoceros, Baluchitherium, from the Oligocene of Mongolia. Bulletin of the American Museum of Natural History 72, 1-73.

Gromova, V., 1959. Gigantskie nosorogi. Trudy Paleontology Institut Akademii Nauk SSSR 71, 1-164.

Osborn, H. F., 1923. Baluchitherium grangeri, a giant hornless rhinoceros from Mongolia. American Museum Novitates 78, $1-15$.
Pilgrim, G. E., 1910. Notices of new mammalian genera and species from the Tertiaries of India. Records of the Geological Survey of India 40, 63-71.

Prothero, D. R., 2005. The evolution of North American rhinoceroses. Cambridge University Press, Cambridge.

Prothero, D. R., 2006. After the dinosaurs: the age of mammals. Indiana University Press, Bloomington.

Prothero, D. R., Emry, R. J., 2005. The Terrestrial Eocene-Oligocene Transition in North America. Cambridge University Press, Cambridge.

Prothero, D. R., Foss, S. E., 2007. The evolution of artiodactyls. John Hopkins University Press, Baltimore.

Prothero, D. R., Schoch, R. M., 1989. The evolution of perissodactyls. Clarendon Press, New York.

Qiu, Z. X., Wang, B. Y., 2007. Paracerathere fossils of China. Palaeontologia Sinica, new series C29, 1-396.

Sen, S., Antoine, P.-O., Varol, B., Ayyildiz, T., Sözeri, K., 2011. Discovery of the giant rhinocerotoid Paraceratherium Forster Cooper, 1911 (Mammalia, Perissodactyla) and other vertebrates in the Oligocene and middle Miocene deposits of the Igdir-Kagizman Basin, Eastern Turkey. Naturwissenschaften $98,407-423$.

Teilhard de Chardin, P., 1926. Description des Mammifères tertiaires de Chine et de Mongolie. Annales de Paléontologie 15, 1-52. 